\title{
Ефективність відеоларингоскопа при анестезіологічному забезпеченні операцій у хворих на флегмону шиї
}

\author{
V. YU. ARTEMENKO모 O. O. BUDNYUK
}

Odesa National Medical University

Ambulance Hospital "INTO-SANA"1, Odesa

\section{EFFICIENCY OF VIDEOLARYNGOSCOPY DURING GENERAL ANESTHESIA IN PATIENTS WITH PHLEGMON OF THE NECK}

\begin{abstract}
У статті представлено результати анестезіологічного забезпечення 75 хворих на флегмону шиї. В проведеному дослідженні було встановлено, що основними причинами тяжкої інтубації трахеї у хворих з флегмоною шиї є: обмеження відкривання рота менше 3 см, набряк гортані і ригідний надгортанник при одонтогенній флегмоні порожнини рота і шиї. При інтубації трахеї за допомогою лампового ларингоскопа частота тяжких інтубацій становила 62,6 \%, із них 9,3 \% інтубацій були невдалими. Частота тяжких інтубацій трахеї при використанні фібробронхоскопа і відеоларингоскопа “Flaplight” склала 8,1 і 7,9 \% відповідно порівняно з ламповим ларингоскопом. Таким чином, відеоларингоскоп “Flaрlight” можна рекомендувати для інтубації трахеї у хворих $з$ флегмоною шиї.
\end{abstract}

The article presents the results of anesthetic management of 75 patients with phlegmon of the neck. In this study it was found that the main causes of severe tracheal intubation in patients with phlegmon of the neck were the limitation of mouth opening is less than $3 \mathrm{~cm}$, rigid and oedema of the epiglottis of the larynx. When tracheal intubation with a standard laryngoscope, the incidence of difficult intubation was $62.6 \%$, of which $9.3 \%$ were unsuccessful. The frequency of difficult tracheal intubation using the fibreoptic and videolaryngoscopy Flaplight was $8.1 \%$ and $7.9 \%$, respectively, compared with a standard laryngoscope. Thus, videolaryngoscopy Flaplight can be recommended for tracheal intubation in patients with phlegmon of the neck.

Постановка проблеми і аналіз останніх досліджень та публікацій. Однією із особливостей анестезіологічного забезпечення операцій з приводу флегмон шиї є ургентність ситуації, наявність сепсису, імуносупресія різного генезу, тяжка супутня патологія, а також високий ризик тяжкої ларингоскопії та інтубації трахеї, що зумовлено запальною контрактурою нижньої щелепи із значним обмеженням відкривання рота [1].

За даними різних авторів, при розвитку глибоких флегмон шиї забезпечити адекватну анестезію за допомогою місцевої анестезії майже неможливо, а методом вибору є загальна анестезія зі штучною вентиляцією легень [1].

Ускладнення при хірургічному лікуванні флегмон шиї можуть бути причиною критичних станів у ранньому післяопераційному періоді і потребувати негайної анестезіологічної допомоги у відновленні прохідності дихальних шляхів.

Дані щодо переваг того чи іншого методу забезпечення прохідності дихальних шляхів у щелепно-лицьовій хірургії досить суперечливі.
Так, за даними Єлизарьєвої Н. Л. (2005), традиційний спосіб інтубації трахеї за допомогою ларингоскопа, порівняно з фіброоптичною інтубацією, не забезпечує адекватних показників гемодинаміки, вентиляції та оксигенації, що підвищує ризик інтраопераційних ускладнень. Але при цьому фіброоптична інтубація трахеї при щелепно-лицьових операціях в умовах збереженого самостійного дихання і свідомості дуже погано суб'єктивно переноситься (60 \%) і ускладнюється повторним кашлем, стридором, артеріальною гіпертензією і тахікардією.

На сьогодні відомо близько 22 способів і пристроїв, які рекомендують для підтримання прохідності дихальних шляхів, а саме це відеоларингоскопи “Storz” та оптичні ларингоскопи (“Glidescope”, “Airtraq”). Серед їх недоліків слід вважати те, що вони $є$ одноразовими, не дешевими, а головне не зареєстровані в Україні. При чудових оптичних можливостях ларингоскопа “Airtraq” його недоліком вважають відсутність мобільності ендотрахеальної трубки завдяки каналу, в якому вона перебуває під час прямої ларингоскопії [5]. 
На жаль, сьогодні в Україні більшість сучасних оптичних ларингоскопів не доступна для практичних анестезіологів.

Мета роботи: порівняти ефективність різних методів забезпечення прохідності дихальних шляхів при анестезіологічному забезпеченні операцій у хворих на флегмону шиї.

Матеріали і методи. Відповідно до поставленої мети дослідження основу клінічного матеріалу становили спостереження за 75 хворими на флегмону шиї, яким проводили анестезіологічне забезпечення та інтенсивну терапію на базах КУ “Одеська обласна клінічна лікарня” і КУ “Одеська міська клінічна лікарня № 11” за період з 2006 до 2015 р.

Контрольна група (n=37) - хворі на флегмону шиї, у яких надання медичної допомоги проводили відповідно до наказу МОЗ України № 181 від 24.03.2009 р. “Протокол надання медичної допомоги хворим з розлитою флегмоною шиї”. Забезпечення прохідності дихальних шляхів проводили за загальноприйнятою методикою за допомогою інтубації трахеї ламповим ларингоскопом або трахеостомії.

Основна група (n=38) - хворі на флегмону шиї, яким анестезіологічне забезпечення проводили, враховуючи дані шкали прогнозування складної інтубації трахеї “Індекс тяжкої інтубації” і ступеня тяжкості інтубації трахеї за Кормаком-Ліхеном. Інтубацію трахеї проводили за допомогою фібробронхоскопа (ФБС) або ларингоскопа "Flaplight" із відеоадаптером (ВЛАР).

У проведеному дослідженні анестезіологічне забезпечення у хворих на флегмону шиї здійснювали під внутрішньовенною анестезією зі штучною вентиляцією легень. Інтраопераційний моніторинг проводили відповідно до Гарвардського протоколу.

Дозвіл на проведення дослідження отримано комісією з питань біоетики. Статистичну обробку виконували за допомогою статистичної програми “STATSOFT STATISTICA 6.0”. Для об’єктивної оцінки реальності та ступеня достовірності результатів вимірювань різних показників у хворих програмний комплекс застосовував обчислення критерію $\chi^{2}$ Пірсона. Вірогідність різниць середніх показників оцінювали при 95 \% довірчому інтервалі (95 \% ДІ).

\section{Результати досліджень та їх обговорення.} У хворих із флегмоною шиї при інтубації трахеї за допомогою лампового ларингоскопа, ФБС і ВЛАР частота тяжких інтубацій становила 62,6, 8,1 і 7,9 \% відповідно $\left(x^{2}=18,78\right.$; $\left.<<0,01\right)$.

При порівнянні ефективності ВЛАР і ФБС вірогідної різниці не отримано $(\mathrm{P}>0,05)$. Абсолютний ризик виникнення тяжкої інтубації трахеї у пацієнтів, яким інтубацію трахеї виконували за допомогою лампового ларингоскопа, був 54 \% (95 \% ДІ: 0,38-0,68), а абсолютний ризик при застосуванні ВЛАР і ФБСІТ був вірогідно нижчим - 7 і 8 \% відповідно (табл. 1). Так, при застосуванні ВЛАР різниця в частоті тяжкої інтубації трахеї становила 46 \% порівняно з ламповим ларингоскопом. Частота тяжкої інтубації трахеї в основній групі склала всього 14 \% (ВР=0,14 при 95 \% ДІ: 0,04-0,45) порівняно $з$ контрольною групою, а зниження ії̈ частоти при застосуванні ВЛАР було нижчим - 85 \%. Враховуючи той факт, що в основній групі відношення шансів менше 1 (ВШ=0,07 при 95 \% ДІ: 0,01-0,27), можна сказати, що використання ВЛАР для зниження частоти тяжкої інтубації трахеї у хворих із флегмоною шиї $є$ ефективним методом.

Така ефективність ВЛАР у хворих із флегмоною шиї пояснюється рухливістю кінчика клинка відеоларингоскопа і кращим оглядом ларингеальних структур за рахунок підсиленої оптики, що дозволяє краще підняти надгортанник і збільшує частоту легкого ступеня ларингоскопічної картини за Кормаком-Ліхеном. Таким чином, забезпечення належних умов для оптимальної ларингоскопії дало можливість уникнути труднощів під час інтубації трахеї і забезпечити безпеку хворого під час даної процедури при обмеженні відкривання рота і наявності набряку гортані.

Таблиця 1. Ефективність різних методів інтубації трахеї

\begin{tabular}{||l|c|c|c||}
\hline \multirow{2}{*}{\multicolumn{1}{|c|}{ Показники }} & \multicolumn{2}{c||}{ Методи інтубації трахеї (95 \% ДІ) } \\
\cline { 2 - 4 } & ламповий ларингоскоп & ВЛАР* & ФБС* \\
\hline Абсолютний ризик & $0,54(0,38-0,68)$ & $0,07(0,02-0,20)$ & $0,08(0,02-0,21)$ \\
\hline Зниження абсолютного ризику & - & $0,46(0,25-0,61)$ & $0,46(0,25-0,61)$ \\
\hline Відносний ризик & - & $0,14(0,04-0,45)$ & $0,15(0,05-0,46)$ \\
\hline Зниження відносного ризику (\%) & - & $0,85(0,47-1,14)$ & $0,85(0,47-1,14)$ \\
\hline Відношення шансів & - & $0,07(0,01-0,27)$ & $0,08(0,02-0,29)$ \\
\hline \hline
\end{tabular}

Примітка. *- порівняно з ламповим ларингоскопом. 
Висновки. 1. При інтубації трахеї за допомогою лампового ларингоскопа частота тяжких інтубацій становила 62,6 \%, із них 9,3 \% були невдалими.

2. Частота тяжких інтубацій трахеї при використанні фібробронхоскопа і відеоларингоскопа

\section{СПИСОК ЛІТЕРАТУРИ}

1. Алгоритмы при трудной интубации и экстубации трахеи : монография / О. А. Тарабрин, В. В. Суслов, А. А. Буднюк, И. Л. Басенко. - Одесса, 2012. - 140 с.

2. Губанов Д. С. Эндоскопическая тактика при трудной интубации / Д. С. Губанов, К. К. Скворцов, И. 3. Хажалия // Український журнал малоінвазивної та ендоскопічної хірургіï. - 2010. - T. 14, № 3. - С. 56.

3. Videolaryngoscopy in the management of the difficult airway: a comparison with the Macintosh blade / K. Stroumpoulis, A. Pagoulatou, M. Violari [et al.] // Eur. J. Anesthesiol. - 2009. Vol. 26 - P. 218-222.
“Flaplight” була 8,1 і 7,9 \% відповідно $\left(x^{2}=18,78\right.$; $\mathrm{p}<0,01)$ порівняно з ламповим ларингоскопом.

3. У хворих із флегмоною шиї для інтубації трахеї можна також рекомендувати відеоларингоскоп "Flaplight".

4. Learning curves of the Glidescope, the McGrath the Airtraq laryngoscopes: a manikin study / G. L. Savoldelli, E. Schiffer, C. Abegg [et al.] // Eur. J. Anesthesiol. - 2009. - Vol. 26 - P. 554558.

5. Muallem M. The use of the GlideScope to facilitate nasotracheal intubation: in patients with a difficult airway / M. Muallem, A. Baraka // Eur. J. Anesthesiol. - 2009. - Vol. 26 - P. 179.

6. Chetan B. Raval. Airway management in submandibular abscess patient with awake fibreoptic intubation / Chetan B. Raval, Mond. Suleiman Khan // M. E. J Anesth. - 2012. - P. 647-651.

Отримано 21.07.15 